\title{
Analisis Kinerja Pegawai Kantor Desa Dalam Memberikan Pelayanan Administrasi Kepada Masyarakat
}

\author{
Pransiska Ropi \\ Sistem Informasi, Fakultas \\ Teknologi Informasi, Universitas \\ Kristen Satya Wacana, Salatiga, \\ 50711, Indonesia \\ 682017411@student.uksw.edu
}

\author{
Agustinus Fritz Wijaya \\ Sistem Informasi, Fakultas \\ Teknologi Informasi, Universitas \\ Kristen Satya Wacana, Salatiga, \\ 50711, Indonesia \\ agustinus.wijaya@uksw.edu
}

\author{
Frederik Samuel Papilaya \\ Sistem Informasi, Fakultas \\ Teknologi Informasi, Universitas \\ Kristen Satya Wacana, Salatiga, \\ 50711, Indonesia \\ samuel.papilaya@uksw.edu
}

\begin{abstract}
Abstrak-Pelayanan adalah upaya membantu mempersiapkan, atau mengurus kebutuhan orang lain. Kinerja aparatur pemerintah desa Siabu dalam memberikan pelayanan administrasi yang baik kepada masyarakat terlihat dari Indikator Kinerja, apakah pelayanan tersebut sudah mencapai indikator ini oleh aparatur kelurahan dalam memberikan pelayanan administrasi kepada masyarakat. Tujuan penelitian ini adalah untuk mendeskripsikan dan menganalisis kinerja pegawai Kantor desa Mayak dalam memberikan pelayanan administrasi yang berfokus pada pelayanan administrasi kependudukan yaitu pembuatan Surat Pengantar KTP (Kartu Tanda Penduduk) kepada masyarakat desa Mayak. Penelitian ini menggunakan pendekatan kualitatif deskriptif dengan melakukan wawancara langsung dengan aparat desa dan masyarakat desa. Berdasarkan hasil penelitian dapat disimpulkan bahwa pelayanan administrasi kependudukan yang dilakukan oleh pegawai Kantor desa Mayak masih belum optimal. Diketahui juga bahwa disiplin pegawai kantor desa Mayak masih kurang baik, aparat desa masih kurang tanggap terhadap keluhan masyarakat dalam memberikan pelayanan. Sehubungan dengan hal tersebut, disarankan agar Pemerintah Kantor desa Mayak Kabupaten Seluas menerapkan sistem SOP (Standar Operasional Prosedur), meningkatkan disiplin, agar kedepannya pelayanan yang diberikan kepada masyarakat lebih baik lagi. UndangUndang Nomor 6 Tahun 2014 berupaya mengembalikan konsep dan wujud desa ke asalnya, desa atau yang dikenal dengan sebutan desa adalah nama suatu kesatuan masyarakat hukum yang berwenang mengatur dan mengurus kepentingan masyarakat setempat berdasarkan asal usul dan adat istiadat yang diakui dalam sistem pemerintahan nasional dan berada di Kecamatan, Kawasan desa juga dapat dibentuk, dihapus, atau digabungkan dengan memperhatikan asalnya atas prakarsa masyarakat dengan persetujuan Pemerintah Kabupaten dan DPRD. Undang-undang ini secara substansial berimplikasi pada pemberdayaan aparatur pemerintah desa dan juga masyarakat desa. mengatasi keterbatasan fasilitas yang tidak memadai dengan menggunakan sarana lain untuk mengolah data yang mempunyai fungsi sama, meningkatkan kinerja pegawai
\end{abstract}

dengan melatih sikap disiplin, melakukan pelatihan mandiri.

Kata Kunci-Kinerja, Pegawai, Pelayanan, Administrasi, Kantor desa.

\section{PENDAHULUAN}

Pada dasarnya manusia membutuhkan pelayanan, bahkan pada kenyataannya dapat dikatakan pelayanan tidak dapat dipisahkan dari kehidupan manusia. Masyarakat selalu menuntut pelayanan publik yang berkualitas dari pemerintah, padahal tuntutan tersebut seringkali tidak sesuai dengan harapan karena secara empiris pelayanan publik yang terjadi selama ini masih berbelit-belit, lambat, mahal, dan melelahkan. Sesuai dengan Undang-Undang Nomor 25 Tahun 2009 tentang Pelayanan Publik, yaitu Pelayanan Publik adalah suatu kegiatan atau rangkaian kegiatan dalam rangka memenuhi kebutuhan pelayanan sesuai dengan peraturan perundang-undangan bagi setiap warga negara dan penduduk atas barang, jasa, dan pelayanan administrasi yang disediakan oleh masyarakat. penyedia jasa. . Kecenderungan ini terjadi karena masyarakat masih diposisikan sebagai pihak yang "melayani" bukan dilayani. Hal tersebut berdampak negatif terhadap perkembangan kualitas pelayanan yaitu masih seringnya upaya perbaikan pelayanan terabaikan dan belum berkembangnya inovasi pelayanan serta kurangnya insentif bagi pemerintah daerah untuk meningkatkan kualitas pelayanan. Penyelenggaraan pemerintahan desa merupakan sub sistem dari sistem penyelenggaraan pemerintahan, sehingga desa memiliki kewenangan untuk mengatur masyarakatnya. Sesuai dengan Undang-Undang Nomor 6 Tahun 2014 tentang desa, Pemerintah desa adalah penyelenggara urusan pemerintahan oleh.

\section{TINJAUAN PUSTAKA}

Analisis berasal dari bahasa inggris yaitu analyzis yang artinya: mengupas, menguraikan, mengulas, dan membahas. Analisis merupakan proses mengurai suatu hal menjadi berbagai unsur yang terpisah untuk memahami sifat, hubungan, dan peranan masing-masing 
unsur. Dalam linguistik, analisa atau analisis adalah kajian yang dilaksanakan terhadap sebuah bahasa guna meneliti struktur bahasa secara mendalam. Steers, 1985 (Dwiyanto, 2005) analisis secara umum sering juga disebut pembagian. Analisis atau pembagian berarti pemecah belahan atau penguraian bagian dari keseluruhan yang selalu berhubungan dan suatu keseluruhan adalah terdiri dari atas bagian-bagian. Ditinjau dari sudut kualitas pelayanan masyarakat,. Peraturan sebagai salah satu sarana dalam mencapai bukan hanya satu kata yang tidak bermakna dan diabaikan tanpa ditaati. Dalam rangka mencapai tujuan, peraturan harus benar-benar ditaati oleh setiap individu yang menjadi obyek dari peraturan tersebut.

1. Pengertian Kinerja

Dalam Kinerja Dapat kita artikan sebagai berikut Menurut Para Ahli Yaitu; Kinerja menurut Bambang Kusriyanto dalam A.A Anwar Prabu Mangkunegara (2007) kinerja diartikan sebagai hasil kerja secara kualitas dan kuantitas yang dicapai oleh seorang pegawai dalam malaksanakan tugasnya sesuai dengan tanggung jawab yang diberikan kepadanya.

Menurut kamus Bahasa Indonesia Kinerja dapat diartikan yaitu, suatu yang dapat dicapaiPrestasi yang diperlihatkan,serta kemampuan kita yang kerja.

Menurut Stewart organisasi publik menjadi "multi purpose organization" Stewart and Clarke, 1988 (Abdul Kadir, 2015). Dalam praktiknya, Sebagai organisasi publik maka kinerja pemerintahan dapat diketahui dan diukur melalui pelaksanaan fungsi, tugas dan tanggungjawab aparatur negara dalam melayani masyarakat. Apakah pemerintah sudah melaksanakan fungsi, tugas dan tanggungjawabnya akan terlihat melalui sikap serta penilaian masyarakat terhadap institusi pemerintahan tersebut. Jadi kualitas pelayanan (quality of service) sekaligus merupakan gambaran dari produktifitas aparat pemerintahan.

\section{Indikator Kinerja}

Menurut Sudaryanti indikator kenerja merupakan sesuatu yang akan dihitung dan diukur serta digunakan sebagai dasar untuk menilai atau melihat tingkat kinerja, baik dalam tahap perencanaan, pelaksanaan, maupun setelah kegiatan selesai. Indikator kinerja digunakan untuk meyakini bahwa kinerja organisasi kerja yang bersangkutan menunjukkan peningkatan kemampuan dalam rangka menuju tujuan dan sasaran yang telah ditetapkan.

\section{Pengukur Kinerja}

Meliputi Beberapa aspek yaitu:

a. Kualitas Kerja (Quality of Work)

b. Ketetapan (Prompness)

c. Inisiatif (Initiative)

d. Kemampuan (Capability)

e. Komunikasi (Communication)

Pada era reformasi kinerja bagaikan barang komoditi yang laris dijual. Baik dijual oleh mereka dari kalangan praktisi. Maupun akademisi secara benra apa yang dimaksudkan denan kinerja, bagaimana ukuran kinerja, dan bagaimana upaya untuk meningkatkan kinerja. Jika dilacak kinerja berasal dari
bahasa"Performance" yang artinya daya guna.Menurut Widodo (Merupakan 2005) Kinerja Merupakan suatu Kegiatan dan Menyempurnakan sesuai dengan tanggung Dengan hasil seperti ang diinginkan, Sedankan menurut Sudarto (1999) Bahwa Kinerja Merupaksil sebagai hasil atau unjuk kerja yang dari suatu organisasi yang dilakukan oleh individu yang ditunjukkan secara konkret dan dapat diukur (Dwiyanto, 2005) Analisis secara umum sering kita sebut pembagian. Pembagian berarti pemecah belahan atau uraian bagian dari keseluruh yang selalu berhubungan dari satu keseluruhannya adalah terdiri dari bagian-bagian.peraturan salah satu sarana dalam mencapai bukan hanya satu kata melainkan kata yang idak bermakna dan abaikan tanpa ditaaati. Peraturan harus benar-benar ditaati olah setiap individu bak pun kelompok yang menjadi ibyek perturan tersebut.

Jenis penelitian ini adalah deskriptif menurut Lexy J. Moleong (2007) adalah penelitian yang dimaksudkan untuk memahami fenomena apa yang dialami oleh subjek, misalnya semua perilaku, persepsi, motivasi, tindakan dan lain-lain. Mendeskripsikan bagaimana kinerja pegawai kantor desa dalam memberikan pelayanan publik kepada masyarakat di desa Mayak, sebuah kecamatan di suatu wilayah Kabupaten Bengkayang dengan membenahi kondisi yang ada.

Kantor desa merupakan suatu tempat dimana masyarakat dapat mengaspirasikan keperluan penduduk, maksud dari keperluan penduduk adalah pelayanan publik dan desa merupakan bagian organisasi terkecil dalam suatu Negara. Selanjutnya kantor desa tidak terlepas dari adanya Jenis-jenis Pelayanan, dalam judul skripsi yang peneliti teliti adalah jenis-jenis Pelayanan dalam Administrasi adapun jenis-jenisnya adalah : 1) pelayanan pembuatan surat pengantar Kartu Tanda Penduduk (KTP), 2) pengantar Kartu Keluarga (KK), 3) pengantar surat nikah, 4) pengantar akte kelahiran, 5) pengantar akte kematian. Akan tetapi peneliti hanya berfokus pada pembuatan surat pengantar Kartu Tanda Penduduk (KTP), karena sering adanya permasalahan masyarakat desa Mayak dalam pelayanan terebut.

Salah satu faktor keberhasilan dari kinerja pelayanan dalam sebuah organisasi adalah budaya berorganisasi. Budaya organisasi, tidak terlepas dari peran dan komitmen pimpinan dan sumber daya organisasi tersebut.

\section{METODE PENELITIAN}

Metode yang digunakan dalam penelitian ini yaitu deskriptif kualitatif yang bertujuan untuk memperoleh gambaran yang utuh tentang sesuatu dari sudut pandang manusia, kualitatif berkaitan dengan gagasan, persepsi, pendapat atau kepercayaan orang yang diteliti dan semua tidak dapat diukur dengan angka, jenis metode yang digunakan adalah deskriptif dengan menggunakan metode kualitatif. Pendekatan yang bertujuan untuk memberikan gambaran atau penjelasan secara sistematis, faktual dan akurat. Alasan penelitian ini menggunakan metode kualitatif karena dalam metode ini data yang dihasilkan adalah data deskriptif yang diperoleh dari data 
tertulis, kata dan dokumen yang bersumber dari sumber atau informasi yang diteliti dan dapat dipercaya, sedangkan jenis penelitian yang digunakan adalah studi kasus dimana-mana. Peneliti berusaha mencari makna, menyelidiki proses tersebut dan memperoleh pemahaman serta memahami sedalam mungkin apa yang diketahui.

Di era reformasi, kinerja ibarat komoditas yang paling laris. Barang bagus dijual oleh orang-orang dari kalangan praktisi. Serta akademisi sebenarnya apa yang dimaksud dengan kinerja, apa saja ukuran kinerja, dan bagaimana upaya untuk meningkatkan kinerja. Jika dilacak performance berasal dari bahasa "Performance" yang artinya usability. Menurut Widodo 2005) Performance Is an Activity and Improvement Sesuai dengan tanggung jawab Dengan hasil yang diinginkan, Sedankan menurut Sudarto (1999) Bahwa Prestasi Merupaksil adalah hasil atau prestasi dari sebuah organisasi yang dilakukan oleh individu yang konkrit dan terukur. Penelitian kualitatif bertujuan untuk memperoleh gambaran lengkap tentang sesuatu menurut perspektif manusia yang cermat. Penelitian kualitatif berkaitan dengan ide, persepsi, pendapat, dan keyakinan orangorang yang teliti dan tidak dapat diukur dengan angka. Jenis metode yang digunakan adalah deskriptif yaitu menggunakan pendekatan kualitatif untuk memberikan gambaran atau penjelasan yang sistematis, faktual dan akurat tentang kinerja Kantor desa Pegai dalam pelayanan kepada masyarakat.

\section{HASIL DAN PEMBAHASAN}

Berdasarkan pendapat dari lembagaAdministrasi Negara dalam buku Sistem Administrasi Negara Republik Indonesia menerangkan bahwa gambaran mengenai tingkat pencapaian pelaksanaan suatu kegiatan,program,kebijaksanaan dalam ewujudkan sasaran,tujuan, misi dan visi organisasi.

Dan pada bagian ini juga dipaparkan hasil wawancara dengan penelitian yang telah ditentukan,adalah masyarakat desa Mayak yang pernah melakukan pengurusan surat keterangan baik lahir,Kartu Keluarga,meninggal,maupun pindah keluar dan masuk menjadi penduduk dan pemertintah desa yaitu kepala desa,sekretaris desa,bendahara desa dan staff lainnya.didalam sebuah desa ada palayanan Admistrasi yaitu sebagai berikut;

Pelayanan dalam bahasa Indonesia (2008) berasal dari kata layan yang artinya membantu (mengurus) yang sangat diperlukan seseorang, kata pelayanan mempunyai arti perihal atau melauyani jadi pelayanan adalah suatu proses pemenuhan kebutuhan melalui aktivitas orang lain yang langsung. Pelayanan yang diberikan harus tanpa memandang status,pangkat dan golongan dari suatu masyarakat, masyarakat mempunyai hak yang sama untuk memperoleh suatu pelayanan yang ada landasan yang bersifat umum dalam bentu sebuaqh pedoman tata laksana pelayanan umum. Adanya suatu fungsi pemerintah adalah untuk menyelenggara pelayanan umum yang bertujuan untuk mewujudkan kesejahteraan, masyarakat,pelayanan umum yang memuaskan dapat terwujud apabila dilaksanakan secara efisien,efektif,berkeadilan,trasnparan, dan akuntabel.

Dalam sebuah filsafat Administrasi, Siagian (1973) mengatakan bahwa: administrasi adalah keseluruhan proses pelaksanaan keputusan-keputusan yang telah diambil dan pelaksanaan itu pada umumya ditentukan oleh dua orang manusia atau lebih dari dua orang manusia supaya bias mencapai tujuan yang telah ditentukan dari sebelumnya." Efisiensi dan efektivitas menyelenggarakan pemerintah desa, pemerintah desa harus mendukung dengan tata usaha ynag benar dan bagus, administrasi desa sangat penting bagi kegiatan penyelenggaraan pemerintah desa. Pemerintah desa akan berjalan lancar ketika didukung oleh sistem tata usahavatau administrasi yang benar,rapi dan tertib.

Banyak dalam pandangan negative yang terbentuk dalam organisasi yang ada di kantor desa Mayak terhadap kualitas dengan demikian kepuasan masyarakat terhadap layanan dapat dijadikan kinerja hasil penelitian yang dilakukan melalui tanggapan tentang kualitas layanan pegawai dalam pelaksanaa tugas di kantor desa Mayak.

Kinerja pegawai di kantor desa Mayak telah dilakukan secara sederhana dengan menggunakan instrument skala sikap pegawai yang bekerja di kantor desa Mayak adalah aparatur negara yang di tuntut untuk memberikan pelayanan yang optimal terhadap masyarakat khusus nya dalam pelayanan administrasi. Dalam kamus besar Bahasa Indonesia dikatakan kinerja adalah sesuatu yang dicapai prestasi yang diperlihatkan,dan kemampuan kinerja dari pengertian diatas kinerja merupakan kemampuan seseorang dalam melaksanakan tugas atau pekerjaannya.

Pelayanan dalam desa kegiatan atau rangkaian kegiatan dalam rangka pemenuhan kebutuhan pelayanan sesuai dengan peraturan perundang-undangan. Dalam melakukan kinerja,peran sebagai penilai sangat lah penting tanpa adanya penilaian,penilaian kinerja tidak akan berjalan secara efesien,penilaian pada bagaian kepegawaian dan umum,untuk penilaian pegawai saaat ini adalah dari segi absensi.

\section{KESIMPULAN}

Berdasarkan data yang diperoleh selama penelitian dapat disimpulkan bahwa kinerja pelayanan pegawai pada masyarakat di desa Mayak, hal ini terlihat dari masa pelayanan administrasi. yang terkadang tidak sesuai dengan komunitas. Faktor pendukung dalam pelayanan yang diberikan pegawai kepada masyarakat telah dilaksanakan prosedur yang dikeluarkan oleh pemerintah serta adanya fasilitas pendukung dalam memberikan pelayanan kepada masyarakat sehingga dapat memudahkan pegawai dalam memberikan pelayanan. Kegiatan pelayanan di desa Mayak berupa: Pelayanan administrasi (surat - menyurat dan perizinan); layanan kesehatan (posyandu dan puskesmas); pelayanan gotong royong dan pemeliharaan taman / jalan) dan masalah keamanan dan ketertiban serta masalah kesejahteraan sosial (bantuan sosial dan pengentasan kemiskinan). Kejujuran sangat penting, bukan hanya orang lain tetapi 
juga terhadap diri sendiri. Terhadap orang lain seorang manusia haruslah dapat bekerja sama berdasarkan kepada saling percaya. Kejujuran berhubungan dengan kemampuan sendiri kita harus jujur terhadap apa yang kita buat dan apa yang kita tidak buat. Inilah sikap yang tidak profesionalisme. Kejujuran profesionalisme akan menghasilkan produk yang unggul dan terus-menerus dapat bersaing. Sikap profesionalisme ini ditandai oleh seorang manusia unggul yang mengetahui kapan dia berdiri sendiri dan kapan dia harus bekerja sama.

\section{DAFTAR PUSTAKA}

A. Kusnendar, "Kinerja Pemerintah Desa Dalam Pelayanan Publik Di Desa Cijulang Kecamatan Cijulang Kabupaten Pangandaran," J. Ilm. Ilmu Adm. Negara, Pp. 1-8, 2018.

D. D. Putra, Rifdan, And F. Umar, "Kinerja Pegawai Dalam Pelayanan Publik Di Kelurahan Mallawa Kecamatan Mallusetasi Kabupaten Barru," J. Econ. Bus. Manag., Vol. Volume Iv, No. C, Pp. 79-91, 2017, [Online]. Available: Http://Ojs.Unm.Ac.Id/Tomalebbi/Article/Download /6739/3850.

D. Putra, "Analisis Kinerja Pegawai Dalam Memberikan Pelayanan Kepada Masyarakat Di Kantor Camat Pasir Penyu Kabupaten Indragiri Hulu," 2013.

D. O. Maria, "Analisis Kinerja Pegawai Kantor Desa Dalam Memberikan Pelayanan Administrasi Kepada Masyarakat," Pp. 1-56, 2017.

H. W. Harahap, "Hadi Wahyudi Harahap 157024046," 2018.

U. S. Baderan And Y. Ingo, "Kinerja Pegawai Dalam Pelayanan Administrasi Di Kantor Kecamatan Boliyohuto Kabupaten Gorontalo," Publik (Jurnal Ilmu Adm., Vol. 6, No. 2, P. 127, 2018, Doi: 10.31314/Pjia.6.2.127-134.2017.

U. S. Utara, "Universitas Sumatera Utara 4," No. 140903060, Pp. 4-16, 2003.

Y. Marande, “Jurnal Ilmiah Administratie,” No. 73, 2017. 